\title{
Detection, identification, and typing of Listeria species from baled silages fed to dairy cows
}

\author{
D. M. Nucera, ${ }^{*}$ M. A. Grassi, $†$ P. Morra, $†$ S. Piano, ${ }^{*}$ E. Tabacco, ${ }^{*}$ and G. Borreani ${ }^{* 1}$ \\ *Department of Agricultural, Forest and Food Sciences (DISAFA), University of Torino, 10095 Grugliasco (TO), Italy \\ †Department of Veterinary Sciences, University of Turin, 10095 Grugliasco (TO), Italy
}

\begin{abstract}
Anaerobiosis, critical for successful ensilage, constitutes a challenge in baled silages. The loss of complete anaerobiosis causes aerobic deterioration and silages undergo dry matter and nutrient losses, pathogen growth, and mycotoxin production. Silage may represent an ideal substrate for Listeria monocytogenes, a pathogen of primary concern in several cheeses. The aim of this research was to investigate the occurrence of Listeria in baled silage fed to cows producing milk for a protected designation of origin cheese, and to characterize isolates by repetitive sequence-based PCR. Listeria spp. were detected in 21 silages and L. monocytogenes in 6 out of 80 of the analyzed silages; $67 \%$ of positives were found in molded zones. Results of the PCR typing showed genotypic homogeneity: 72.9 and $78.8 \%$ similarity between strains of Listeria spp. $(\mathrm{n}=56)$ and L. monocytogenes $(\mathrm{n}=24)$, respectively. Identical profiles were recovered in molded and nonmolded areas, indicating that contamination may have occurred during production. The application of PCR allowed the unambiguous identification of Listeria isolated from baled silages, and repetitive sequence-based PCR allowed a rapid and effective typing of isolates. Results disclose the potential of the systematic typing of Listeria in primary production, which is needed for the understanding of its transmission pathways.
\end{abstract}

Key words: baled silage, Listeria contamination, mold count, aerobic deterioration, plastic film damage

\section{INTRODUCTION}

In intensive dairy farms, forage crops are harvested as silage throughout the world to reduce feeding costs. Among the various silage conservation methods, wrapped bales are commonly used in Europe to preserve

Received January 21, 2016.

Accepted April 6, 2016.

${ }^{1}$ Corresponding author: giorgio.borreani@unito.it the quality of forage from meadows (Wilkinson and Toivonen, 2003; McEniry et al., 2007) and are gaining popularity in the United States in the last decade (Han et al., 2006; Arriola et al., 2015). Baled silage is often made from herbage that is wilted more extensively and presented more limited fermentation than conventional bunker silo silage, as it reduces the number of bales per hectare, plastic consumption, and costs, and can be more convenient when fed to animals (Han et al., 2006; McEniry et al., 2007; Tabacco et al., 2013). Unfortunately, the increased DM content also tends to increase fungal growth in wrapped forages (O'Brien et al., 2008; Tabacco et al., 2013), thus increasing hygienic issues as well as the risk of mycotoxicosis (O'Brien et al., 2007) and Listeria contamination (Fenlon et al., 1989). In bale silages, more than $40 \%$ of the silage DM stored is within $120 \mathrm{~mm}$ of the film cover and the reduced total thickness of the combined layers of stretch film on the bale side, usually $70 \mu \mathrm{m}$ (4 layers) to $105 \mu \mathrm{m}$ (6 layers), could be expected to make individually wrapped bales more susceptible to oxygen ingress (Forristal and O'Kiely, 2005). Even small holes that can occur on farm due to both mechanical and wildlife factors can result in quantitative DM losses because of mold growth, especially in conserved forages with higher DM contents (McNamara et al., 2001; Müller et al., 2007). Air penetration into the silage stimulates aerobic bacteria, yeasts, and molds and causes aerobic deterioration (O'Brien et al., 2007; Borreani and Tabacco, 2008a). Silage that has suffered aerobic spoilage has an increased probability of being contaminated by Listeria spp. (Fenlon et al., 1989; Borreani et al., 2012).

Listeria monocytogenes is a gram-positive, rod-shaped microorganism that is ubiquitous in the dairy farm environment (Vilar et al., 2007; Fox et al., 2009). Listeria monocytogenes is a foodborne pathogen, an agent that causes listeriosis: a serious invasive disease that affects both humans and a wide range of animals (Adams and Moss, 1995). Its occurrence in raw milk and food processing environments (dairy, fish, pork, and so on) has also been widely reported (Kells and Gilmore, 2004; Lianou and Sofos, 2007). In most cases, contamination 
is due to postprocessing environmental cross-contamination of foods, as heat treatments kill the organism. Because of the absence of a pasteurization step, raw milk products, especially soft cheeses, are considered high-risk products (Lunden et al., 2004). Dairy cows may be directly exposed to L. monocytogenes through the ingestion of improperly fermented silage $(\mathrm{pH}>5.0)$ contaminated before ensiling (Fenlon, 1988), and $L$. monocytogenes may then reach bulk tanks as a result of fecal contamination during milking, as also reported for spore-forming bacteria (Vissers et al., 2007). Other than Listeria detection, currently strain typing has largely been applied to explore subtype frequency and distribution: some authors applied repetitive element sequence-based PCR (REP) for characterizing isolates collected from dairy primary production as well as from the food processing environment (Harvey et al., 2004; Van Kessel et al., 2005; Chou and Wang, 2006), indicating the putative transmission/contamination paths.

Hence, the aims of the study were to assess the occurrence of Listeria spp. and L. monocytogenes in baled silage fed to dairy cows destined for cheese production, and identify management and silage production practices associated with the presence of the microorganism. Moreover, typing by rep-PCR has been carried out to investigate pathogen dissemination and putative routes of contamination.

\section{MATERIALS AND METHODS}

A survey was carried out over 2 agricultural years (2007-2008 and 2009-2010) in the western Po plain (Italy) on 20 dairy farms (Italian Friesian breed) that produced milk (about 28,000 kg/d) for a cheese-producing plant $\left(45^{\circ} 29^{\prime} 19^{\prime \prime} \mathrm{N}, 8^{\circ} 39^{\prime} 07^{\prime \prime} \mathrm{E}\right)$. The farms were all located in a $20-\mathrm{km}$ area around the processing plant: 14 farms were as close as $2 \mathrm{~km}$ from the plant, another 4 were $8 \mathrm{~km}$ away, and the remaining 2 were 15 and 20 $\mathrm{km}$ away. Each farm was visited 4 times (one for each season), and a detailed questionnaire (with questions on feed production and management) was presented to the farmers in each visit, and one already sealed bale, ready for feeding, was examined and sampled on each farm (for a total of 80 bales).

\section{Bale Sample Collection}

One bale per visit was randomly selected from those ready to be fed to animals. The diameter and height of each bale were measured and the polyethylene cover was carefully examined, looking for visible holes or damages. After the wrapping film had been removed, the visible surface area of each mold patch was measured, according to the published method (Borreani and Tabacco, 2010). The percentage of the total surface area affected by mold growth was then calculated for each bale. The thickness of the wrapping film covering the curved side was measured with 4 replicates using a micrometer (Digimatic Micrometer MDC-lite series 293, Mytutoyo Corp., Kamagawa, Japan). To obtain samples for microbiological, chemical, and fermentative analyses, 4 samples were taken using a steel core sampler (45 mm diameter) from a depth of 0 to $540 \mathrm{~mm}$ from the bale surface, in 4 positions in which no molds or spoilage were visible. The sampling points of this set of samples were spaced around the circumference of the bale at positions of about $0,90,180$, and $270^{\circ}$ on the bale side, at mid-point between the ends. The 4 samples were combined to provide one sample per bale (unaltered parts). When surface patches covered by mold were present, 2 to 6 samples were also taken from these parts from a depth of 0 to $120 \mathrm{~mm}$ from the surface and combined to provide one sample per bale (altered parts). Two different steel corers were used to sample the bale parts that were with or without visible fungal contamination. The corers were disinfected after each sampling operation using $95 \%$ industrial methylated spirit. The samples were immediately stored at 4 to $6^{\circ} \mathrm{C}$ before analysis, which was conducted later the same day. Sampling was performed, according to literature (Müller et al., 2011), by a limited number of people (the authors ET and GB). The same sampling protocol was followed at the same sampling time in each farm to avoid differences in sampling procedure that could have influenced the analytical result. On each farm visit, farmers were requested to complete a pre-determined questionnaire giving details on the history of the sampled silage bale, with information on the forage crop, wilting management, ensiling and wrapping procedures, the type and color of film wrap used, the number of film-wrap layers applied, bale hauling, and bale storage management. Days of conservation were calculated from the day the bale was wrapped to when it was sampled in the survey.

\section{Sample Preparation and Analyses}

Each silage sample was thoroughly mixed under aseptic conditions and divided into 3 sub-samples. The first sub-sample was analyzed for DM concentration, by oven drying it at $60^{\circ} \mathrm{C}$ until constant weight. The dried samples were air equilibrated, weighed, ground in a Cyclotec mill (Tecator, Herndon, VA) to pass a $1 \mathrm{~mm}$ screen, and analyzed for total nitrogen (TN) by combustion (nitrogen analyzer, Primacs SN, Skalar, Breda, the Netherlands), for crude protein $(\mathrm{TN} \times 6.25)$, for NDF and ADF, according to the published protocol (Robertson and Van Soest 1981), and for ash by com- 
bustion at $550^{\circ} \mathrm{C}$ for $3 \mathrm{~h}$. The hemicellulose content was calculated as the difference between NDF and ADF.

Considering the second wet silage sub-sample, $30 \mathrm{~g}$ was transferred to a sterile homogenization bag, suspended 1:10 wt/vol in a peptone physiological salt solution (PPS: $1 \mathrm{~g}$ of neutralized bacteriological peptone and $9 \mathrm{~g}$ of sodium chloride per liter), and homogenized for $4 \mathrm{~min}$ in a laboratory Stomacher blender (Seward Ltd., London, UK) for the microbial counts. The mold and yeast counts were determined by preparing serial dilutions and using the pour plate technique with 40.0 $\mathrm{g} / \mathrm{L}$ of yeast extract glucose chloramphenicol agar (YGC agar, Difco, West Molesey, Surrey, UK). Petri dishes were incubated at $25^{\circ} \mathrm{C}$ for 3 and $5 \mathrm{~d}$ for yeast and mold, respectively, and then the mold and yeast colony-forming units were enumerated separately on plates that yielded 1 to $100 \mathrm{cfu}$ per Petri dish. Mold and yeast colony-forming units were enumerated separately, according to their macromorphological features. The water activity $\left(\mathbf{a}_{\mathbf{w}}\right)$ of the silage was measured at $25^{\circ} \mathrm{C}$ on a fresh sample using an AquaLab Series 3TE (Decagon Devices Inc., Pullman, WA), which adopted the chilled-mirror dew point technique.

Considering the third wet silage sub-sample, $30 \mathrm{~g}$ was transferred to a homogenization bag, suspended 1:10 $\mathrm{wt} / \mathrm{vol}$ in deionized water, and homogenized for $4 \mathrm{~min}$ in a laboratory Stomacher blender (Seward Ltd., London, UK), for quantification of $\mathrm{pH}$ and $\mathrm{NH}_{3}-\mathrm{N}$, through the use of specific electrodes. The nitrate content was determined in the water extract, through semiquantitative analysis, using Merckoquant test strips (Borreani and Tabacco, 2008b).

About $50 \mathrm{~g}$ of the same sub-sample was homogenized and extracted for $4 \mathrm{~min}$ in a Stomacher blender in $\mathrm{H}_{2} \mathrm{SO}_{4} \quad 0.05 \quad M$ at an acid-to-sample material (fresh weight) ratio of $5: 1$. An aliquot of $40 \mathrm{~mL}$ of silage acid extract was centrifuged at $3,622 \times g$ for $4 \mathrm{~min}$ at $20^{\circ} \mathrm{C}$, and the supernatant was filtered with a $0.20-\mu \mathrm{m}$ syringe filter and used for quantification of lactic and monocarboxylic acids (acetic, propionic, and butyric acids) with an HPLC (Agilent Technologies, Santa Clara, CA; Canale et al., 1984). Ethanol was determined by HPLC, coupled to a refractive index detector, on a Aminex HPX-87H column (Bio-Rad Laboratories, Richmond, $\mathrm{CA}$ ). The analyses were performed isocratically under the following conditions: mobile phase $0.0025 \mathrm{M} \mathrm{H}_{2} \mathrm{SO}_{4}$, flow rate $0.5 \mathrm{~mL} / \mathrm{min}$, column temperature $37^{\circ} \mathrm{C}$, and injection volume $100 \mu \mathrm{L}$. Duplicate analyses were performed for all the determined parameters.

\section{Listeria Detection and Identification}

The ISO 170 method (EN ISO 11290-1:1996+A1:2004; ISO, 1996) was applied to all collected samples, using 25-g aliquots. The enriched broth for each sample was then streaked onto Oxoid chromogenic listeria agar (OCLA CM 1080, Oxoid, Milan, Italy) and selective PALCAM Agar (CM 0877 B; Oxoid). Plates were incubated at $37^{\circ} \mathrm{C}$ for 24 to $48 \mathrm{~h}$. The most probable number (MPN) technique was also used, together with the ISO method, to retrieve Listeria present in low concentration in silage. Briefly, $10 \mathrm{~g}$ samples were 1:10 diluted in buffered peptone water (CM1049, Oxoid) and then 2 serial dilutions were prepared. Three milliliters of each dilution was inoculated in 3 tubes with $9 \mathrm{~mL}$ of Fraser broth, for a final total of 9 tubes. These were incubated at $31^{\circ} \mathrm{C}$ for $48 \pm 2 \mathrm{~h}$ and then each sample tube was streaked onto OCLA and PALCAM agar. Five colonies, if present, were selected from OCLA (L. monocytogenes) or PALCAM (other Listeria species) for all the positive samples, and then used for further analyses. In particular, colonies on OCLA with a typical $L$. monocytogenes appearance were confirmed through a species-specific PCR (D'Agostino et al., 2004). The other colonies presenting typical Listeria spp. morphology on PALCAM but no lecithinase halo on OCLA were identified through 16SrDNA sequencing $(600 \mathrm{bp})$, according to the manufacturer's instructions (Micro seq 500 16S rDNA Bacterial Sequencing Kit). The generated sequences were compared with those present in the GeneBank database, using BLASTn sequence similarity searching. Before PCR were performed, colonies were broth cultured (using brain heart infusion broth-BHI; Oxoid) at $37^{\circ} \mathrm{C}$ overnight and then $2 \mathrm{~mL}$ of broth culture was used for DNA extraction by means of the MBIO microbial kit [CABRU, SAS Biassono (MB), Italy]. The extracted DNA was used for both the identification and the characterization PCR assays. The amplifications generated by $16 \mathrm{SrDNA}$ PCR were purified and then sent to an external laboratory (IGA Technology Services, Udine, Italy) for sequencing.

\section{Listeria Characterization}

Listeria characterization was performed using enterobacterial repetitive intergenic consensus (ERIC) and REP primers, according to the published protocol (Jersek et al., 1999) with minor modifications (Nucera et al., 2013). Fingerprints were analyzed with Bionumerics software (v 2.0, Applied Maths, Kortrijk, Belgium); similarity between fingerprints was determined by means of the Dice coefficient using optimization and position tolerance values, as previously described (Nucera et al., 2013). Results were then combined and a dendrogram was generated by the unweighted pair group method with arithmetic mean. Shared profiles were defined as those found in one or more strains, 
whereas unique profiles were those found in a single strain.

\section{Statistical Analysis}

All the analyses were performed using SAS v. 9.1 for Windows (SAS Institute Inc., Cary, NC) and differences were considered statistically significant when $P<$ 0.05. A first set of analyses was performed comparing the altered and the unaltered areas considering DM (g/ $\mathrm{kg})$, $\mathrm{CP}(\mathrm{g} / \mathrm{kg}$ of $\mathrm{DM}), \mathrm{pH}, \mathrm{a}_{\mathrm{w}}$, nitrate concentration (mg/kg of DM), organic acids (lactic, acetic, propionic, and butyric, $\mathrm{g} / \mathrm{kg}$ of $\mathrm{DM})$, ethanol $(\mathrm{g} / \mathrm{kg}$ of $\mathrm{DM})$, ash $(\mathrm{g} / \mathrm{kg}$ of DM), mold and yeast counts $(\log \mathrm{cfu} / \mathrm{g})$, NDF and $\mathrm{ADF}(\mathrm{g} / \mathrm{kg}$ of $\mathrm{DM})$, and hemicelluloses $(\mathrm{g} / \mathrm{kg}$ of $\mathrm{DM})$. The analyses were carried out using paired $t$ test. The frequency of Listeria in the 2 categories of samples was assessed by means of the $\chi^{2}$ test. In addition, Kruskal-Wallis and Mann-Whitney tests were used to investigate the effects of management factors such as wilting time, baler chamber used, plastic layers applied (n), storage location, bale orientation, height of bale storage, and days of conservation, on holes in the plastic cover, and bale surface covered by molds (expressed in \%). Furthermore, silage that was positive and negative for the presence of $L$. monocytogenes and Listeria spp., within altered and unaltered parts, were compared considering the features that could influence microbiological quality: DM concentration $(\mathrm{g} / \mathrm{kg}), \mathrm{CP}$ $(\mathrm{g} / \mathrm{kg}$ of $\mathrm{DM}), \mathrm{pH}, \mathrm{a}_{\mathrm{w}}$, nitrate concentration $(\mathrm{mg} / \mathrm{kg}$ of DM), organic acids (lactic, acetic, propionic, and butyric, $\mathrm{g} / \mathrm{kg}$ of $\mathrm{DM})$, ethanol $(\mathrm{g} / \mathrm{kg}$ of $\mathrm{DM})$, ash $(\mathrm{g} /$ $\mathrm{kg}$ of DM), mold and yeast counts (log cfu/g), NDF and $\mathrm{ADF}(\mathrm{g} / \mathrm{kg}$ of $\mathrm{DM})$, and hemicelluloses $(\mathrm{g} / \mathrm{kg}$ of
DM). The analyses were carried out using the $t$-test for equal/nonequal variances, where the homogeneity of variance assumption was met/not accomplished.

\section{RESULTS}

\section{Chemical and Fermentative Composition of Bale Silage}

A total of 80 bales were examined and sampled in the survey. Bales were made from 3 different crops: permanent meadow, alfalfa, and Italian ryegrass. The mean values and the range of variations of DM content, nutritional characteristics in terms of NDF, ADF, hemicelluloses, CP, nitrate and ash contents, and fermentative profiles in terms of $\mathrm{pH}$, lactic and volatile fatty acids, ethanol, and $\mathrm{NH}_{3}-\mathrm{N}$ contents are reported in Table 1. Both the chemical composition and fermentative profiles encompassed a wide range of situations that are representative of bale silage quality in northern Italy. The DM content showed a wide range of variability, with values typical of direct ensiling to high DM haylage for permanent meadow silages, whereas alfalfa and Italian ryegrass showed less variability. The fermentation showed $\mathrm{pH}$ ranging from 4.12 to $6.22, \mathrm{a}_{\mathrm{w}}$ from 0.78 to 1.00 , lactic acid from $<0.01$ to $74.7 \mathrm{~g} / \mathrm{kg}$ of DM, acetic acid from $<0.01$ to $20.2 \mathrm{~g} / \mathrm{kg}$ of DM, and butyric acid from $<0.05$ to $17.8 \mathrm{~g} / \mathrm{kg}$ of DM.

\section{Bale Management Factors}

Data on the bale silage production and management, the effects of managerial factors on plastic damage, and bale surface covered by mold are reported in Table 2 .

Table 1. Chemical composition and fermentation variables of bales $(\mathrm{n}=80)$ sampled on 20 farms in northwest Italy

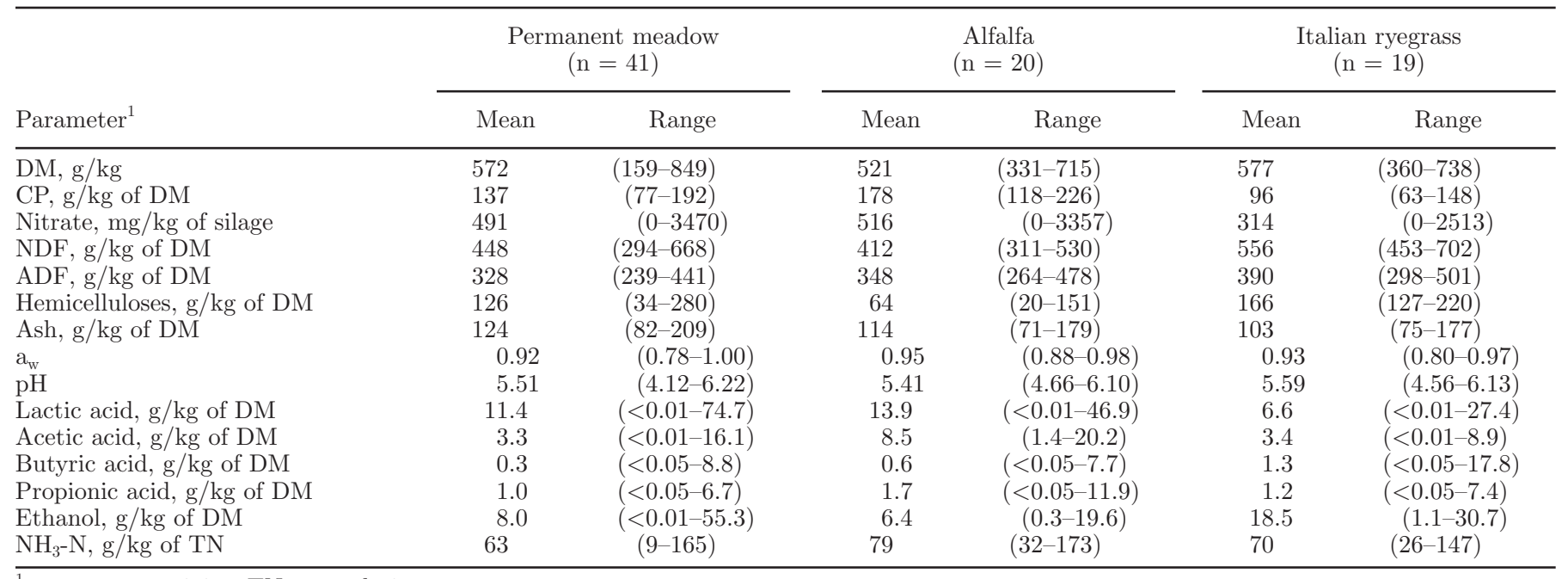

${ }^{1} \mathrm{a}_{\mathrm{w}}=$ water activity; $\mathrm{TN}=$ total nitrogen. 
Table 2. Crop type and bale management factors and relationship with plastic cover damages, extent of spoiled area on the bale surface, and proportion of bales positive for Listeria spp.

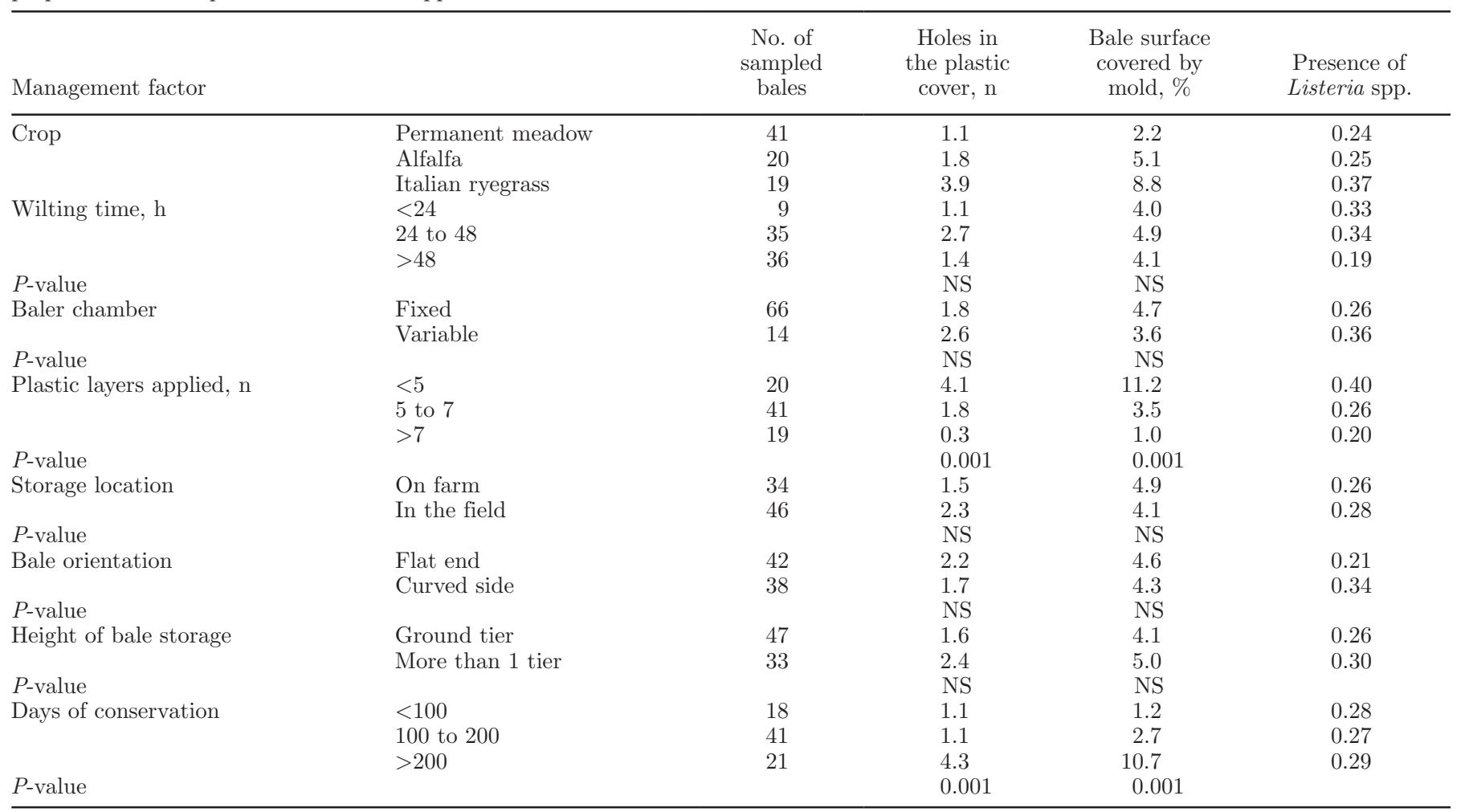

The majority of forages were wilted for at least $24 \mathrm{~h}$ and baled with a fixed chamber baler $(89$ and $83 \%$, respectively). Farmers declared that the bales were wrapped within $4 \mathrm{~h}$ after baling on all the farms. All bales were wrapped using commercial polyethylene stretch film from different manufacturers and of different colors (16 were wrapped in white, 30 in light green, 34 in greenishbrown). About two-thirds of the bales were wrapped in 5 to 7 layers of plastic film, as established from a measurement of the plastic thickness on the curved side of the bale, whereas 20 bales were wrapped with less than 5 layers of plastic and 19 with more than 7 layers. Just over half the bales (58\%) were wrapped and stored in the field with the remainder being transported to the storage area on the farm before wrapping. About half of the bales were stored in a single tier on the ground and on their flat end (59 and $53 \%$, respectively). No farms used net or other protection on their bales during storage. The plastic cover was visibly damaged on 39 bales, with 22 bales having more than 2 visible holes in their plastic cover. Visible mold growth was present on 57 out of 80 bales, with 21 bales having more than $5 \%$ of the surface covered by molds. Damage to the plastic cover and the fungal coverage on the bale surface were affected by the amount of plastic applied and by the time of conservation, with bales being wrapped in less than 5 layers and conserved for more than $200 \mathrm{~d}$ having the highest number of holes and the largest surface covered by molds. The proportion of bales positive to Listeria spp. was higher than 0.30 when wilting time was less than $48 \mathrm{~h}$, the bales were baled with a variable chamber, the bales were wrapped with less than 5 layers of plastic, and the bales were conserved on their curved side.

The correlations between the surface covered by molds, bale management factors, and chemical and microbial composition of the silage samples from unaltered parts are reported in Table 3. The surface covered by molds showed negative correlation with the nominal number of plastic layers applied on the curved side, whereas it was positively correlated with the length of conservation, the number of holes in the plastic cover, and the butyric acid concentration. Interestingly, the butyric acid concentration was also positively correlated with the number of holes in the plastic cover and the conservation time. The DM content of silages was positively correlated with wilting time and $\mathrm{pH}$ and negatively correlated with $\mathrm{NH}_{3}-\mathrm{N}$, and lactic and acetic acids. Other silage variables were variously intercorrelated.

Altered parts had lower DM and ethanol contents and higher values of $\mathrm{pH}$, water activity, yeast and mold 


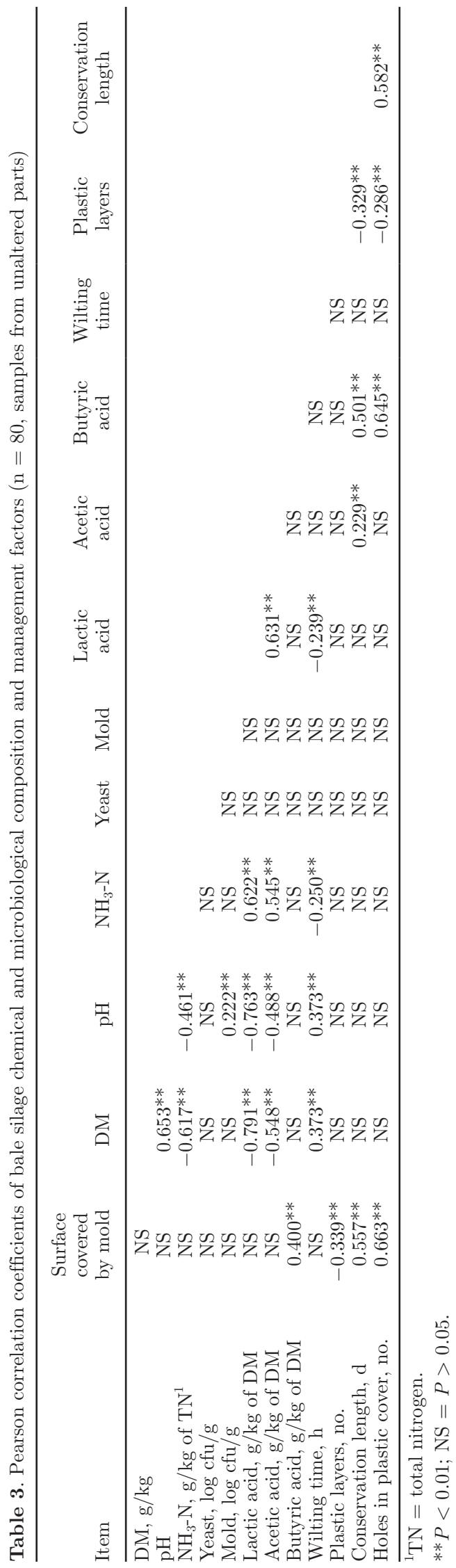

Journal of Dairy Science Vol. 99 No. 8, 2016 counts, and NDF and ADF concentrations than the unaltered parts (Table 4). Listeria spp. presence was higher in the bale parts that were visibly altered and where fungal growth was evident.

When the unaltered parts of silages were considered in respect of the presence or absence of $L$. monocytogenes and Listeria spp. (Table 5), $\mathrm{pH}$ tended to be higher $(P$ $=0.10)$ and yeast count greater $(P=0.030)$ in samples that were positive for the presence of Listeria. When the altered parts were considered, propionic acid was greater $(P=0.044)$ in samples that were positive for the presence of Listeria. It was interesting to note that samples that were negative for the presence of Listeria had a numerically greater nitrate content than those that were positive for both altered and unaltered parts.

\section{Listeria Detection and Identification}

Listeria spp. were detected in 22 bales (27.5\%) considering jointly MPN and ISO methods. The microorganism was isolated both from altered and unaltered parts in 4 bales. It was isolated from the altered parts in 13 bales and in the unaltered parts in 5 bales. Only 1 sample $(1.3 \%)$ yielded L. monocytogenes and Listeria spp. together, whereas 5 samples $(6.3 \%)$ yielded L. monocytogenes but no other Listeria species, and 16 samples $(20 \%)$ yielded only nonpathogenic Listeria spp. In 3 samples, colonies were retrieved by the MPN method but no growth was observed when the ISO procedure was applied. In these samples the MPN ranged from 3 to $80 \mathrm{MPN} / \mathrm{g}$. In all other samples $(\mathrm{n}=19)$ tested positive with the ISO method, the MPN value was higher than $300 \mathrm{MPN} / \mathrm{g}$. All other samples ( $\mathrm{n}=$ 58 ) tested negative with the ISO method; the MPN was below $0.3 / \mathrm{g}$. The PCR confirmed all L. monocytogenes positive samples (OCLA) and sequencing (on PALCAM-suspected colonies) allowed 4 and 12 samples harboring Listeria seeligeri and Listeria innocua to be identified, respectively. The one sample that showed colony morphology characteristics for both L. monocytogenes and Listeria spp. was contaminated by $L$. monocytogenes and L. innocua.

Statistical analyses demonstrated a significant difference in Listeria detection between the altered and unaltered areas (Table 4). The comparison between areas also allowed highly significant differences to be identified in the DM concentration, $\mathrm{pH}, \mathrm{a}_{\mathrm{w}}$, yeast and mold counts, $\mathrm{NH}_{3}-\mathrm{N}$, ethanol, $\mathrm{NDF}$, and $\mathrm{ADF}$.

\section{Listeria Characterization}

A total of 80 colonies were processed with both PCR: 48 were L. innocua, $24 \mathrm{~L}$. monocytogenes, and $8 \mathrm{~L}$. seeligeri. All strains were typeable and produced fin- 
Table 4. Microbiological, chemical, and fermentative characteristics of unaltered and altered parts of silage bales (only bales with altered parts were considered in the comparison; $\mathrm{n}=57$ )

\begin{tabular}{|c|c|c|c|c|c|}
\hline \multirow[b]{2}{*}{ Item $^{1}$} & \multicolumn{2}{|c|}{ Unaltered parts } & \multicolumn{2}{|c|}{ Altered parts } & \multirow[b]{2}{*}{$P$-value } \\
\hline & Mean & SEM & Mean & SEM & \\
\hline DM, g/kg & 562 & 16.3 & 510 & 15.5 & 0.028 \\
\hline $\mathrm{pH}$ & 5.72 & 0.08 & 6.57 & 0.16 & $<0.001$ \\
\hline$a_{w}$ & 0.93 & 0.005 & 0.95 & 0.004 & $<0.001$ \\
\hline Nitrate, $\mathrm{mg} / \mathrm{kg}$ of silage & 530 & 121.9 & 459 & 131.7 & NS \\
\hline $\mathrm{NH}_{3}-\mathrm{N}, \mathrm{g} / \mathrm{kg}$ of $\mathrm{TN}$ & 67.6 & 4.70 & 95.5 & 10.2 & 0.015 \\
\hline Yeast, log cfu/g & 3.57 & 0.22 & 6.09 & 0.28 & $<0.001$ \\
\hline Mold, log cfu/g & 2.45 & 0.14 & 4.93 & 0.26 & $<0.001$ \\
\hline Lactic acid, $\mathrm{g} / \mathrm{kg}$ of DM & 11.2 & 1.92 & 7.6 & 1.71 & NS \\
\hline Acetic acid, $\mathrm{g} / \mathrm{kg}$ of DM & 4.8 & 0.5 & 5.1 & 0.77 & NS \\
\hline Propionic acid, $\mathrm{g} / \mathrm{kg}$ of DM & 1.2 & 0.84 & 1.1 & 0.25 & NS \\
\hline Butyric acid, $\mathrm{g} / \mathrm{kg}$ of $\mathrm{DM}$ & 0.7 & 0.3 & 0.5 & 0.24 & NS \\
\hline Ethanol, $\mathrm{g} / \mathrm{kg}$ of DM & 10.6 & 1.67 & 4.5 & 1.29 & 0.005 \\
\hline Ash, $\mathrm{g} / \mathrm{kg}$ of DM & 117 & 3.7 & 109 & 4.5 & NS \\
\hline $\mathrm{CP}, \mathrm{g} / \mathrm{kg}$ of $\mathrm{DM}$ & 137 & 4.6 & 140 & 5.2 & NS \\
\hline $\mathrm{NDF}, \mathrm{g} / \mathrm{kg}$ of DM & 469 & 10.9 & 502 & 13.5 & 0.057 \\
\hline $\mathrm{ADF}, \mathrm{g} / \mathrm{kg}$ of $\mathrm{DM}$ & 348 & 6.7 & 384 & 9.0 & 0.002 \\
\hline Hemicelluloses, $\mathrm{g} / \mathrm{kg}$ of DM & 121 & 6.7 & 119 & 7.5 & NS \\
\hline Listeria spp. presence & 0.11 & - & 0.28 & - & 0.021 \\
\hline
\end{tabular}

${ }^{1} \mathrm{a}_{\mathrm{w}}=$ water activity; $\mathrm{TN}=$ total nitrogen.

gerprints characterized by 10 to 25 and 8 to 18 bands, for the ERIC and REP primers, respectively (data not shown).

The dendrogram of the combination of the 2 PCR results showed a high genetic homogeneity among the isolates: $78.8 \%$ (for L. monocytogenes) and $72.9 \%$ (for $L$. innocua and L. seeligeri). All L. monocytogenes strains were grouped into 2 clusters gathering highly similar isolates; one gathered $42 \%$ of the isolates (similarity $86.2 \%$ ) and the other $58 \%$ (similarity $87.1 \%$ ). As far as
L. innocua and L. seeligeri were concerned, $85 \%$ of $L$. innocua strains were grouped at a similarity of $76.6 \%$, whereas $88.0 \%$ of L. seeligeri strains shared a $77.1 \%$ similarity level (Figure 1). The analysis of the dendrogram allowed the identification of 12 unique types $(7 \mathrm{~L}$. innocua, 4 L. seeligeri, and 1 L. monocytogenes) and 17 profiles (grouping 68 strains) shared with one or more strains (10 L. monocytogenes, $5 \mathrm{~L}$. innocua, and $2 \mathrm{~L}$. seeligeri). Of the shared profiles, 5 (38\% of the strains) grouped together strains isolated from molded surfaces

Table 5. Comparison of microbiological, chemical, and fermentative characteristics of samples that were positive $(+)$ or negative $(-)$ for the presence of Listeria monocytogenes and Listeria spp. within the unaltered and altered parts of the bales

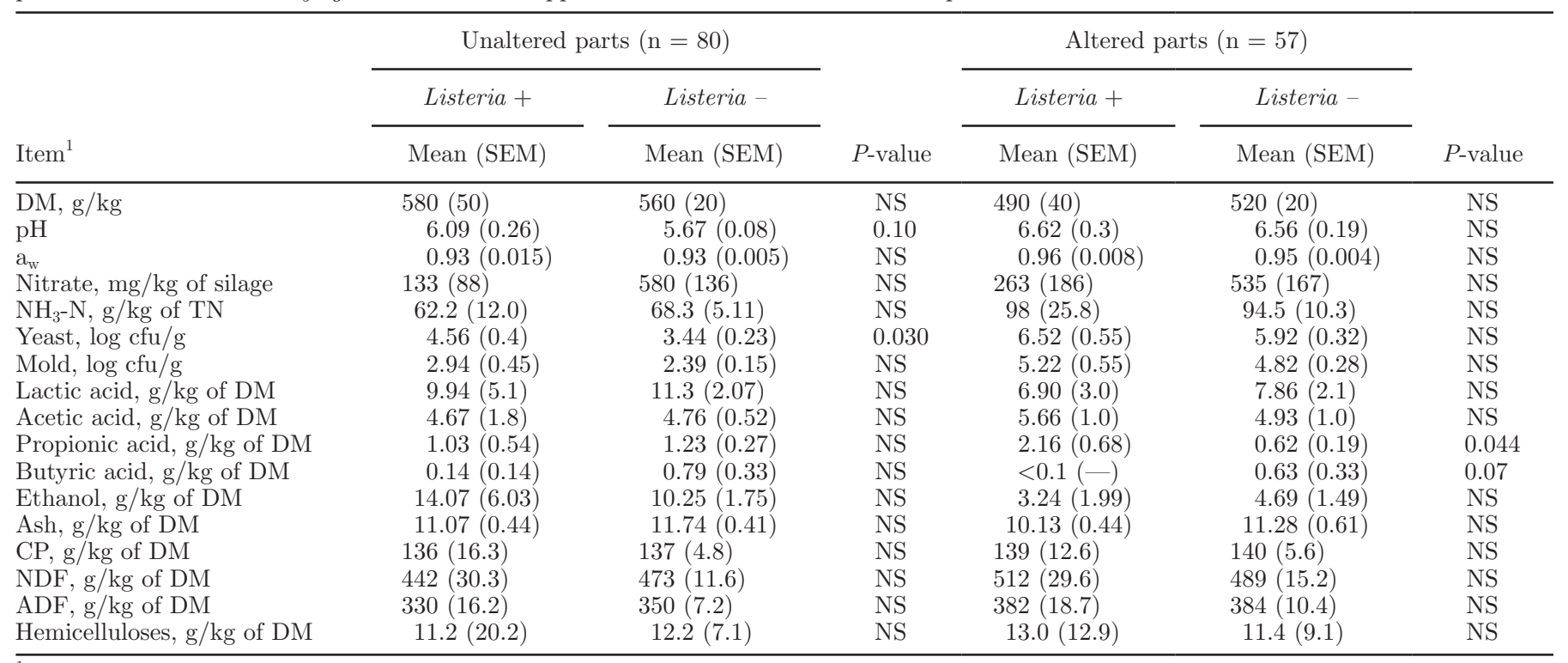

${ }^{1} a_{\mathrm{w}}=$ water activity; $\mathrm{TN}=$ total nitrogen. 
NUCERA ET AL.

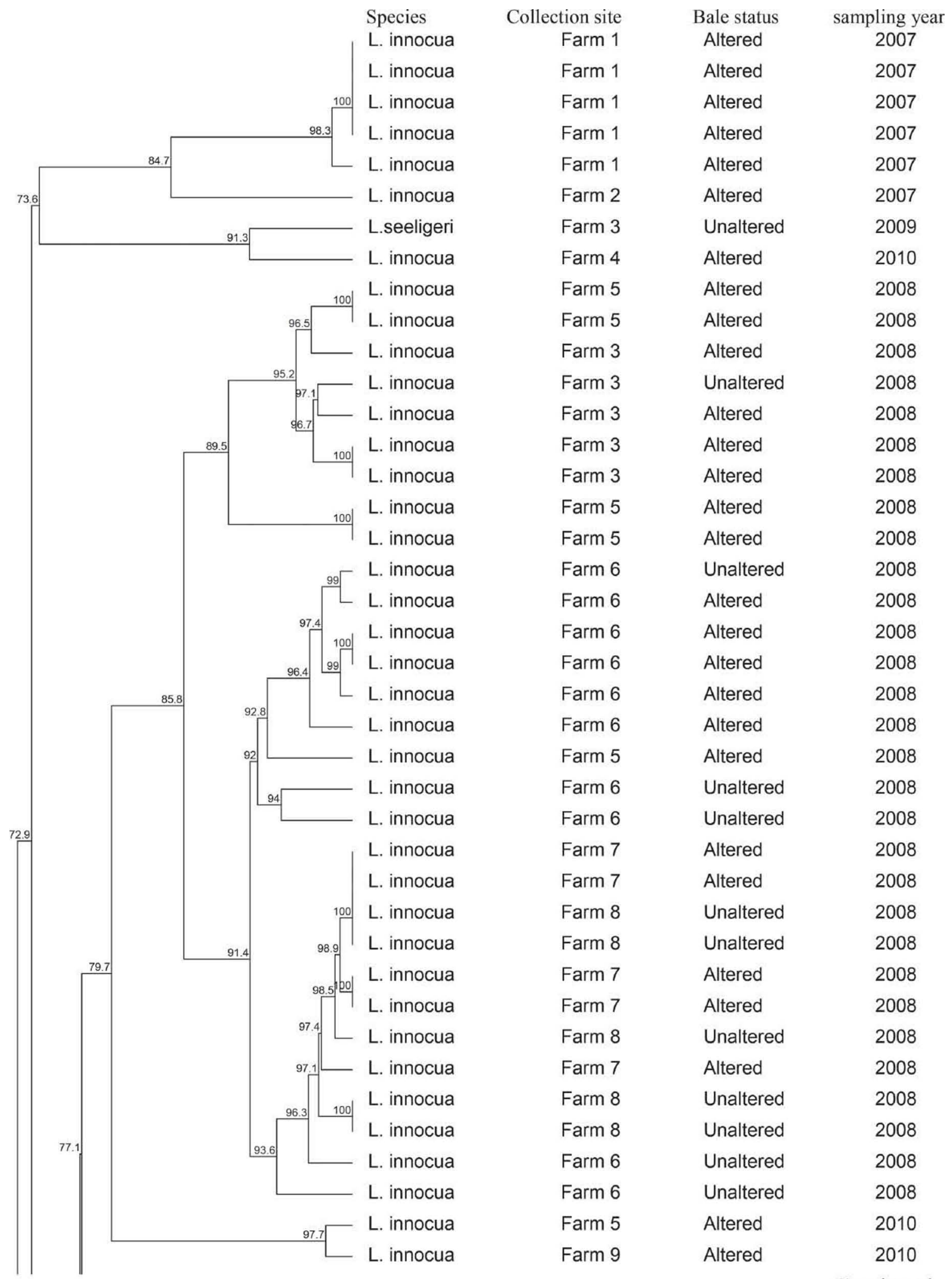

Continued

Figure 1. Dendrogram generated by the combination of repetitive element sequence-based PCR (REP) and enterobacterial repetitive intergenic consensus (ERIC) primers. Each tested strain is reported together with the species it belongs to, the status of the area of the bale from where the strain was isolated, and the detection year. Boxes show PCR profiles with similarity >95\%, therefore indistinguishable. 


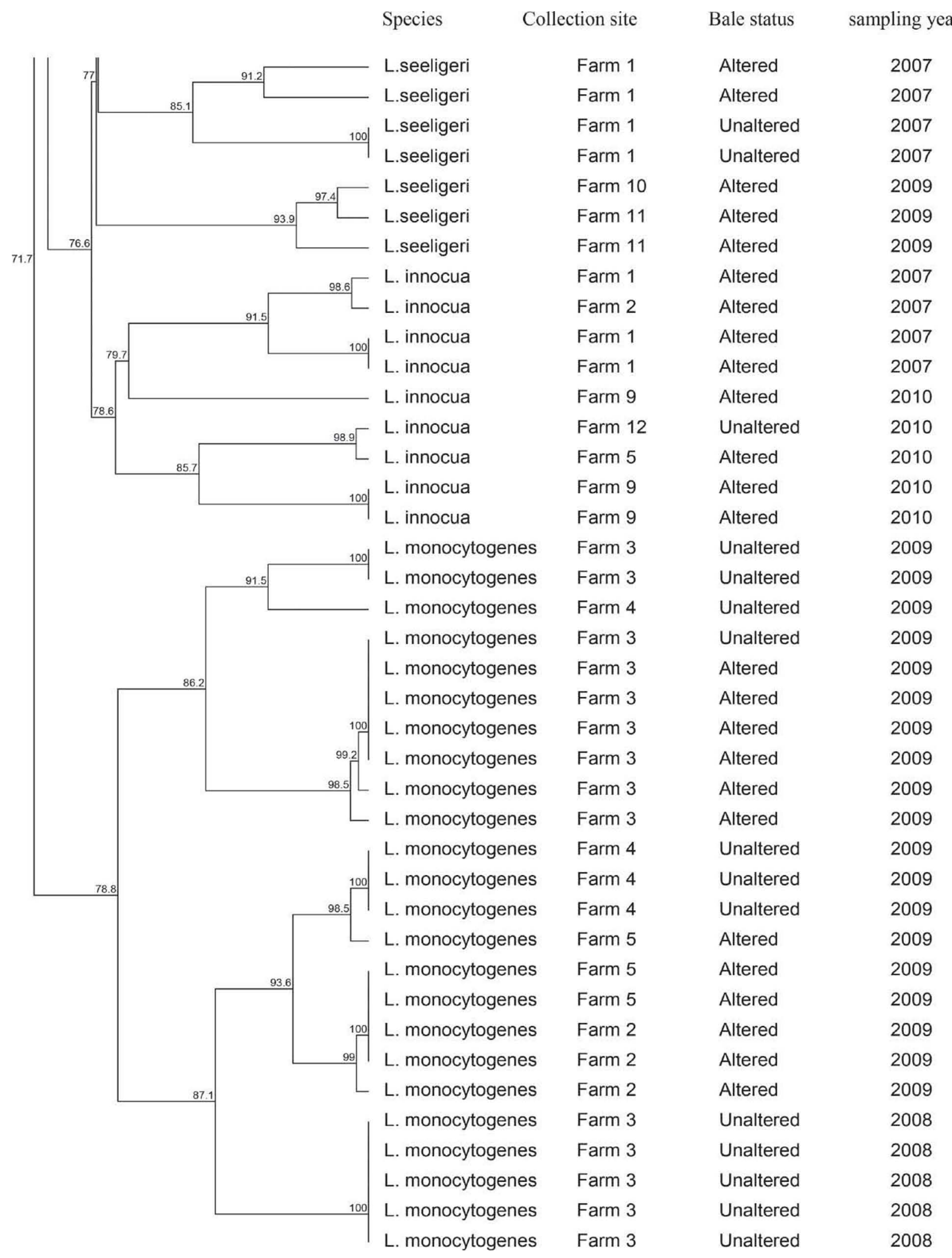

Figure 1 (Continued). Dendrogram generated by the combination of repetitive element sequence-based PCR (REP) and enterobacterial repetitive intergenic consensus (ERIC) primers. Each tested strain is reported together with the species it belongs to, the status of the area of the bale from where the strain was isolated, and the detection year. Boxes show PCR profiles with similarity $>95 \%$, therefore indistinguishable. 
with those isolated from the center of the bales, and 8 (44\% of the strains) grouped samples collected from different farms. Considering the total number of types and the number of tested samples, it appears that the former was greatly increased. Multiple colonies selected from the same sample did not always produce the same PCR profile. One single colony was selected for the PCR characterization from 7 samples, whereas several colonies were selected (from 2 up to 6) from other 10 samples. These resulted in only one PCR profile. Considering the remaining 10 samples, even if from 2 to 5 colonies were selected from each, more PCR profiles were detected (from 2 to 5 ). The highest PCR profiles per sample was attributed to $L$. innocua (1 samples showed 5 profiles), whereas, considering the results of L. seeligeri and L. monocytogenes, 2 PCR profiles were detected in 4 samples each.

\section{DISCUSSION}

The aim of the present study was to elucidate the role of baled silage in Listeria transmission/maintenance in the farm environment by evaluating the prevalence of Listeria and the frequency and distribution of PCR subtypes in baled silage. The results have highlighted that bales may be contaminated by pathogenic and nonpathogenic Listeria species, with a predominance of L. innocua over L. monocytogenes, as also previously reported (Fenlon et al., 1989; Husu et al., 2000; Mohammed et al., 2009). This could be considered positive, even if the World Health Organization (1988) indicated that the presence of nonpathogenic species indicates that environmental conditions are favorable for the survival and growth of the pathogenic species as well. Therefore, particular care should be given in silage preparation and storage, as emphasized by the presented results showing that silages that suffered aerobic spoilage were shown to harbor Listeria species.

The presence of Listeria in bale silage may be due to its presence in the soil and on vegetation, and it has been suggested that these bacteria are a normal part of the microflora of the plant in the field (Husu et al., 2000; Pahlow et al., 2003), and its survival/growth during ensiling occurs, especially in poor management conditions that favor air penetration (Fenlon et al., 1989; Pauly and Tham, 2003). Listeria monocytogenes is resistant to drying, can survive up to $2 \mathrm{yr}$ in dry soil and feces, and is capable of growing over a wide range of temperatures, from 4 to $44^{\circ} \mathrm{C}$ (Membre et al., 1997; Allan et al., 2004). Once the herbage is contaminated by Listeria, its count may increase rapidly after ensiling when the microrganism uses the residual oxygen and the acidic condition characteristics of well-made bales are not yet established (Fenlon and Wilson, 1998). The presence of Listeria on the bales may indicate that the process of acidification had not occurred properly, perhaps in relation to the poor quality of the ensiled forages, which reflects a slow acidification that allows Listeria survival as it could commonly happen in wrapped bale silages. When the anaerobiosis constraint is removed, Listeria may start to multiply and reach hazardous doses (Fenlon and Wilson, 1998).

Results of the present paper support this hypothesis: a significant difference was present in $\mathrm{pH}$ between bales, which allowed the isolation of Listeria, compared with those in which the microorganism was not isolated. Similarly, visible fungal-contaminated silage had a higher $\mathrm{pH}$ and mold and yeast counts than silage parts that were free of visible fungal contamination, in agreement with other reported results (O'Brien et al., 2007). Moreover, the presence of Listeria was highly significantly associated with visually contaminated areas. Overall, the results presented in Table 4 have shown that the presence of Listeria spp. and $L$. monocytogenes was higher in bales characterized by an altered profile due to air penetration in silage. Other authors (Vilar et al., 2007) confirmed the relationship between poor silage quality (indicated by high $\mathrm{pH}$ values) and the presence of Listeria spp. in silage ( 29.5 vs. $6.2 \%$ for $\mathrm{pH}$ above or below 4.5 , respectively). Similarly, several studies have highlighted that clinical listeriosis in ruminants is often associated with feeding poor-quality silage (Adams and Moss, 1995; Driehuis and Oude-Elferink, 2000; Boerlin et al., 2003). Therefore, spoilage prevention of feeds is an important point to prevent herd economic losses due to a spectrum of clinical conditions, including septicemia, meningitis, meningoencephalitis, abortion, and in some instances, death (Ramaswamy et al., 2007). Data from the present research showed that the main managerial factor that could contribute to reduce the incidence of mold growth over the bale surface is the number of stretchplastic layers applied, which reduced the risk of damage to cover and increased the anaerobic status of the bale. Data are in agreement with previously reported results (Keller et al., 1998; Borreani and Tabacco, 2008a), which showed that increasing the number of film layers from 4 to 6 or even 8 often improved air tightness of the bale coverage and significantly reduced mold growth over the bale surface.

The presented results also show that $L$. innocua and L. monocytogenes can be present in areas with low $\mathrm{pH}$ and yeast and mold counts. Similar results were found by other researchers (Ryser et al., 1997) who showed that high-quality corn silage $(\mathrm{pH}<4.0)$ also contains Listeria spp., including L. monocytogenes strains belonging to ribotypes of clinical importance in cases of foodborne listeriosis. In the present study, in all the 
bales where Listeria was detected in the unaltered parts alone, whereas the ISO qualitative method allowed the detection, the MPN results indicated very low concentration of cells (3 to $80 \mathrm{MPN} / \mathrm{g}$ ). This finding probably indicated the presence of the microorganism in the ensiled herbage where it was not able to actively multiply given the ensiling conditions, but it still remained present in the bale in its quiescent phase. On the other hand, the same result could be explained by the soil being contaminated by low density of quiescent cells which may persist over time (Welshimer and DonkerVoet, 1971). These cells are then revitalized by the ISO method, being then able to grow in laboratory media, as it happened in the majority of the herein analyzed samples. However, some cells may be also sublethally injured; therefore, the standard selective enrichment steps do not promote their recovery as efficiently as for the uninjured cells, producing negative results even when qualitative methods are applied (Lee et al., 2011). The discrepancy observed between MPN and ISO methods could then be attributed to the presence in some samples $(\mathrm{n}=3)$ of damaged cells which did not grow (or were outgrown by other flora) in Half-Fraser broth incubated overnight (following the ISO method), but they were able to multiply when grown on Fraser broth for $48 \mathrm{~h}$ (as required by MPN). The higher selective pressure of Fraser broth and the longer incubation time may have allowed the outgrowth of Listeria on the other flora, therefore its detection on plates. The typing results also seem to confirm this hypothesis: finding the same PCR profiles in both the bale centers and altered areas may reflect the presence of strains on the herbage at the moment of the ensiling, but which were still viable after $150 \mathrm{~d}$ of conservation. This finding could disclose the presence of a strain reservoir that is able to survive in correctly fermented bales. The presence of a minimal percentage of oxygen inside the silage mass may allow not only survival, but also growth of the microorganism, which could reach levels as high as $10^{6}$ cfu/g in more than $100 \mathrm{~d}$ (Fenlon and Wilson, 1998). In addition, when the $\mathrm{pH}$ increases (i.e., aerobic deterioration), these strains start to multiply, therefore becoming a putative contamination route for ruminants. In the 1990s, Fenlon et al. (1996) found that silage was the likely source of the introduction of $L$. monocytogenes in the farm environment: they showed that soil samples from pastures of silage-fed ruminants were more likely to host L. monocytogenes than other pastures. The hypothesis of crops as a source of Listeria could be supported by the present work, which has shown that more than one PCR type was retrieved in 10 out of 27 tested samples, suggesting a multiple source of contamination. Forage crops may indeed be contaminated by manure produced on the farm, or by any sort of wildlife, mostly birds and small mammals (Nightingale et al., 2004). The application of ribotyping (Wiedmann et al., 1996) also highlighted a high number of $L$. monocytogenes strains on farms linked to a listeriosis outbreak; however, they did not explain this finding.

Despite the high number of papers published on the successful application of rep-PCR on Listeria isolated from foods (e.g., Jersek et al., 1999; Harvey et al., 2004; Zunabovic et al., 2012) typing data on silage collected samples lack in literature, and the presented resulted were difficult to compare. However, the present data are in agreement with those reported by an earlier study using ribotyping (Ryser et al., 1997). The authors reported a lower number of profiles than samples, indicating that many samples shared the same profile, even though retrieved from different sources. The herein presented results have shown that 17 PCR profiles were shared by 2 or more isolates, and that 8 of them indicated the presence of identical strains in bale silages present on the different farms, as far as $20 \mathrm{~km}$, as shown in the dendrogram of Figure 1. This observation could underline the presence of strains that are able to disseminate from farm to farm, probably through farm machinery or the movement of people, feed, and animals. It should be considered in fact that the samples were all collected in farms that were located in a small geographic areas and that the 2 farthest farms were located $20 \mathrm{~km}$ apart. Moreover, some of the farmers belonging to the cheese producing plant are sharing the machinery needed to produce silage and, sometimes, the feed they produce. It should be considered also that the rep-PCR method herein applied does not allow to differentiate highly similar strains, given the $95 \%$ similarity cut-off chosen for the identification of identical strains. However, research previously published (Chou and Wang, 2006; Zunabovic et al., 2012; Nucera et al., 2013) showed that the discriminatory power of PCR typing is comparable to that of PFGE (the current gold standard typing method for L. monocytogenes). For these reasons, its applicability as a screen typing tool in field research cannot be denied, considering that results on large-scale sampling can be obtained in less time and with the investment of less resources, in comparison to what PFGE would require.

\section{CONCLUSIONS}

The results presented herein highlight that bales may represent a potential hazard mostly when they are not properly conserved (i.e., damage to the plastic film which ensures a safety preservation), as shown by the presence of Listeria more frequently in molded areas than in unaltered ones. Hence, emphasis on the application of good agricultural practices during preparation 
and good hygienic practices during management and distribution of baled silage should be given. In fact, considering the current food law [Regulation (EC) 178/2002 and 852/2004; European Community, 2002, 2004], the farm to fork approach requires food business operators to be responsible for the quality and the safety of products all along the food chain. Therefore, proper silage preparation and storage should be part of the good hygienic practices manual that farms are now required to have to enter the food chain in the European Union. The control of pathogen spread (as evidenced by rep-PCR data) in primary production is necessary mostly in products (such as the one we selected in this paper) in which the presence of $L$. monocytogenes represents a primary concern, to prevent dissemination of the pathogen first in primary production, and then in food-producing factories.

\section{ACKNOWLEDGMENTS}

The authors thank Piero Michele Meda (DISAFA University of Turin, Italy) for the chemical and microbiological analyses, and Sara Lomonaco for her assistance in sequencing data arrangement for NCBI online submission. This work was funded by the Regione Piemonte, Assessorato Qualità, Ambiente e Agricoltura (Italy), project "Incidenza e livello di contaminazione da Listeria monocytogenes negli insilati aziendali e ripercussioni sulle produzioni lattiero casearie nella filiera del Gorgonzola DOP." The authors contributed equally to the work described in this paper.

\section{REFERENCES}

Adams, M. R., and M. O. Moss. 1995. Bacterial agents of foodborne illness. Pages 186-190 in Food Microbiology. The Royal Society of Chemistry, University of Surrey, Guildford, UK.

Allan, J. T., Z. Yan, L. L. Genzlinger, and J. L. Komacki. 2004. Temperature and biological soil effects on the survival of selected foodborne pathogens on a mortar surface. J. Food Prot. 67:2661-2665.

Arriola, K. G., O. C. M. Queiroz, J. J. Romero, D. Casper, E. Muniz, J. Hamie, and A. T. Adesogan. 2015. Effect of microbial inoculants on the quality and aerobic stability of bermudagrass roundbale haylage. J. Dairy Sci. 98:478-485. http://dx.doi.org/10.3168/ jds.2014-8411.

Boerlin, P., F. B. Petzold, and T. Jemni. 2003. Use of listeriolysin O and internalin A in a seroepidemiological study of listeriosis in Swiss dairy cows. J. Clin. Microbiol. 41:1055-1061.

Borreani, G., D. M. Nucera, E. Tabacco, P. M. Meda, P. Morra, and A. Grassi. 2012. Recovery and PCR-based characterization of Listeria strains and investigation on managerial factors influencing its occurrence on farm baled silages. Pages 306-307 in Proc. 16th Int. Silage Conf. MTT Agrifood Research Finland, University of Helsinki, Helsinki, Finland.

Borreani, G., and E. Tabacco. 2008a. New oxygen barrier stretch film enhances quality of alfalfa wrapped silage. Agron. J. 100:942-948. http://dx.doi.org/10.2134/agronj2007.0258.

Borreani, G., and E. Tabacco. 2008b. Low permeability to oxygen of a new barrier film prevents outgrowth of butyric acid bacte- ria in farm corn silage. J. Dairy Sci. 91:4272-4281. http://dx.doi org/10.3168/jds.2008-1151.

Borreani, G., and E. Tabacco. 2010. Use of new plastic stretch films with enhanced oxygen impermeability to wrap baled alfalfa silage. Trans. ASABE 53:635-641. http://dx.doi.org/10.13031/2013.29555.

Canale, A., M. E. Valente, and A. Ciotti. 1984. Determination of volatile carboxylic acids $(C 1-C 5)$ and lactic acid in aqueous acid extracts of silage by high performance liquid chromatography. J. Sci. Food Agric. 35:1178-1182.

Chou, C. H., and C. Wang. 2006. Genetic relatedness between Listeria monocytogenes isolates from seafood and humans using PFGE and REP-PCR. Int. J. Food Microbiol. 110:135-148.

D'Agostino, M., M. Wagner, J. A. Vazquez-Boland, T. Kuchta, R. Kapriskova, J. Hoofar, S. Novella, M. Scortti, J. Ellison, A. Murray, I. Fernandez, M. Kuhn, J. M. Pazlarova, A. Heuvelink, and N. Cook. 2004. A validated PCR-based method to detect Listeria monocytogenes using raw milk as a food model towards an international standard. J. Food Prot. 67:1646-1655.

Driehuis, F., and S. J. W. H. Oude-Elferink. 2000. The impact of the quality of silage on animal health and food safety: A review. Vet. Q. 22:212-216.

European Community. 2002. No 178/2002 of the European Parliament and of the Council of 28 January 2002 laying down the general principles and requirements of food law, establishing the European Food Safety Authority and laying down procedures in matters of food safety. Official J. Eur. Union L 031:1-24.

European Community. 2004. No 852/2004 of the European Parliament and of the Council of 29 April 2004 on the hygiene of foodstuffs. Official J. Eur. Union L 139:1-55.

Fenlon, D. R. 1988. Listeriosis. Pages 7-18 in Silage and Health. B. A. Stark and J. M. Wilkinson, ed. Chalcombe Publications, Marlow Bucks, UK.

Fenlon, D. R., and J. Wilson. 1998. The quantitative assessment of Listeria monocytogenes growth in a laboratory ensiling system allowing limited aerobic spoilage. Grass Forage Sci. 53:292-295.

Fenlon, D. R., J. Wilson, and W. Donachie. 1996. The incidence and level of Listeria monocytogenes contamination of food sources at primary production and initial processing. J. Appl. Bacteriol. 81:641-650

Fenlon, D. R., J. Wilson, and J. R. Weddell. 1989. The relationship between spoilage and Listeria monocytogenes contamination in bagged and wrapped big bale silage. Grass Forage Sci. 44:97-100.

Forristal, P. D., and P. O'Kiely. 2005. Update on technologies for producing and feeding silage. Pages 83-96 in Proc. 14th Int. Silage Conf., Belfast, Northern Ireland, Wageningen Academic Publishers, Wageningen, the Netherlands.

Fox, E., T. O'Mahony, M. Clancy, R. Dempsey, M. O'Brien, and K. Jordan. 2009. Listeria monocytogenes in the Irish dairy farm environment. J. Food Prot. 72:1450-1456.

Han, K. J., M. Collins, E. S. Vanzant, and C. T. Dougherty. 2006. Characteristics of baled silage made from first and second cuttings of wilted and severely-wilted forages. Grass Forage Sci. 61:22-31.

Harvey, J., D. E. Norwood, and A. Gilmour. 2004. Comparison of repetitive element sequence-based PCR with multilocus enzyme electrophoresis and pulsed field gel electrophoresis for typing Listeria monocytogenes food isolates. Food Microbiol. 21:305-312.

Husu, J. R., S. K. Sivelä, and A. L. Rauramaa. 2000. Prevalence of Listeria species as related to chemical quality of farm-ensiled grass. Grass Forage Sci. 45:309-314.

ISO. 1996. ISO 11290-1. Microbiology of food and animal feeding stuffs. Horizontal method for the detection and enumeration of Listeria monocytogenes. Part 1: Detection method. International Organization for Standardization (ISO), Geneva, Switzerland.

Jersek, B., P. Gilot, M. Gubina, N. Klun, J. Mehle, E. Tcherneva, N. Rijpens, and L. Herman. 1999. Typing of Listeria monocytogenes strains by repetitive element sequence-based PCR. J. Clin. Microbiol. 37:103-109.

Keller, T., H. Nonn, and H. Jeroch. 1998. The effect of sealing and of additives on the fermentation characteristics and mould and yeast counts in stretch film wrapped big-bale Lucerne silage. Arch. Anim. Nutr. 51:63-75. 
Kells, J., and A. Gilmore. 2004. Incidence of Listeria monocytogenes in two milk processing environments, and assessment of Listeria monocytogenes blood agar for isolation. Int. J. Food Microbiol. 91:167-174.

Lee, H. Y., L. C. Chai, C. F. Pui, W. C. Wong, S. Mustafa, Y. K. Cheah, Z. M. Issa, M. Nishibuchi, and S. Radu. 2011. Profiling of recovery efficiencies for three standard protocols (FDA-BAM, ISO-11290, and Modified USDA) on temperature-injured Listeria monocytogenes. J. Microbiol. Biotechnol. 21:954-959. http:// dx.doi.org/10.4014/jmb.1012.12034.

Lianou, A., and J. N. Sofos. 2007. A review of the incidence and transmission of Listeria monocytogenes in ready-to-eat products in retail and food service environments. J. Food Prot. 70:2172-2198.

Lunden, J., R. Tolvanen, and H. Korkeala. 2004. Human listeriosis outbreaks linked to dairy products in Europe. J. Dairy Sci. 87(E. Suppl.):E6-E11.

McEniry, J., P. O'Kiely, N. J. W. Clipson, P. D. Forristal, and E. Doyle. 2007. The relative impacts of wilting, chopping, compaction, and air infiltration on the conservation characteristics of ensiled grass. Grass Forage Sci. 62:470-484.

McNamara, K. M., P. O'Kiely, J. Whelan, P. D. Forristal, H. Fuller, and J. J. Lenehan. 2001. Vertebrate pest damage to wrapped baled silage in Ireland. Int. J. Pest Manage. 47:167-172.

Membre, J. M., J. Thurette, and M. Catteau. 1997. Modelling the growth, survival and death of Listeria monocytogenes. J. Appl. Microbiol. 82:345-350.

Mohammed, H. O., K. Stipetic, P. L. McDonough, R. N. Gonzalez, D. V. Nydam, and E. R. Atwill. 2009. Identification of potential on-farm sources of Listeria monocytogenes in herds of dairy cattle. Am. J. Vet. Res. 70:383-388. http://dx.doi.org/10.2460/ ajvr.70.3.383.

Müller, C. E., C. Hultén, and G. Gröndahl. 2011. Assessment of hygienic quality of haylage fed to healthy horses. Grass Forage Sci. 66:453-463. http://dx.doi.org/10.1111/j.1365-2494.2011.00803.x.

Müller, C. E., T. M. Pauly, and P. Uden. 2007. Storage of small bale silage and haylage. Influence of storage period on fermentation variables and microbial composition. Grass Forage Sci. 62:274-283.

Nightingale, K. K., Y. H. Schukken, C. R. Nightingale, E. D. Fortes, A. J. Ho, Z. Her, Y. T. Grohn, P. L. McDonough, and M. Wiedmann. 2004. Ecology and transmission of Listeria monocytogenes infecting ruminants and in the farm environment. Appl. Environ. Microbiol. 70:4458-4467.

Nucera, D. M., S. Lomonaco, A. Costa, P. Morra, and M. A. Grassi. 2013. Diagnostic performance of rep-PCR as a rapid subtyping method for Listeria monocytogenes. Food Anal. Methods 6:868871. http://dx.doi.org/10.1007/s12161-012-9496-1.

O'Brien, M., P. O'Kiely, P. D. Forristal, and H. T. Fuller. 2007. Quantification and identification of fungal propagules in well-managed baled grass silage and in normal on-farm produced bales. Anim. Feed Sci. Technol. 132:283-297.

O'Brien, M., P. O'Kiely, P. D. Forristal, and H. T. Fuller. 2008. Fungal contamination of big-bale grass silage on Irish farms: Predomi- nant mould and yeast species and features of bales and silage. Grass Forage Sci. 63:121-137. http://dx.doi.org/10.1111/j.13652494.2007.00620.x.

Pahlow, G., R. E. Muck, F. Driehuis, S. J. W. H. Oude-Elferink, and S. F. Spoelstra. 2003. Microbiology of ensiling. Pages 31-93 in Silage Science and Technology. Vol. 42. D. R. Buxton, R. E. Muck, and J. H. Harrison ed. ASA, CSSA, SSSA, Madison, WI.

Pauly, T. M., and W. A. Tham. 2003. Survival of Listeria monocytogenes in wilted and additive-treated grass silage. Acta Vet. Scand. 44:73-86

Ramaswamy, V., V. M. Cresence, J. S. Rejitha, M. U. Lekshmi, K. S. Dharsana, S. P. Prasad, and H. M. Vijila. 2007. Listeria - review of epidemiology and pathogenesis. J. Microbiol. Immunol. Infect. 40:4-13.

Robertson, J. B., and P. J. Van Soest. 1981. The detergent system of analysis and its application to human foods. Pages $123-158$ in The Analysis of Dietary Fiber in Food. James W. P. T. and O. Theander, ed. Marcel Dekker, New York.

Ryser, E. T., S. M. Arimi, and C. W. Donnelly. 1997. Effects of pH on distribution of Listeria ribotypes in corn, hay, and grass silage. Appl. Environ. Microbiol. 63:3695-3697.

Tabacco, E., C. Bisaglia, A. Revello-Chion, and G. Borreani. 2013 Assessing the effect of securing bales with either polyethylene film or netting on the fermentation profiles, fungal load, and plastic consumption in baled silage of grass-legume mixtures. Appl. Eng. Agric. 29:795-804.

Van Kessel, J. S., J. S. Karns, L. Gorski, and M. L. Perdue. 2005. Subtyping Listeria monocytogenes from bulk tank milk using automated repetitive element-based PCR. J. Food Prot. 68:2707-2712.

Vilar, M. J., E. Yus, M. L. Sanjuan, F. J. Diéguez, and J. L. RodrıguezOtero. 2007. Prevalence of and risk factors for Listeria species on dairy farms. J. Dairy Sci. 90:5083-5088.

Vissers, M. M. M., F. Driehuis, M. C. Te Giffel, P. De Jong, and J. M. G. Lankveld. 2007. Quantification of the transmission of microorganisms to milk via dirt attached to the exterior of teats. J. Dairy Sci. 90:3579-3582.

Welshimer, H. J., and J. Donker-Voet. 1971. Listeria monocytogenes in nature. Appl. Microbiol. 21:516-519.

Wiedmann, M., J. L. Bruce, R. Knorr, M. Bodis, E. M. Cole, C. I. McDowell, P. L. McDonough, and C. A. Batt. 1996. Ribotype diversity of Listeria monocytogenes strains associated with outbreaks of listeriosis in ruminants. J. Clin. Microbiol. 34:1086-1090.

Wilkinson, J. M., and M. I. Toivonen. 2003. World Silage. Chalcombe Publications, Welton, Lincoln, UK.

World Health Organization. 1988. Informal Working Group on Foodborne Listeriosis. Foodborne listeriosis. Document $\mathrm{n}^{\circ} \mathrm{WHO} / \mathrm{WHE} /$ FOS/88.5. World Health Organization, Geneva, Switzerland.

Zunabovic, M., K. G. Domig, I. Pichler, and W. Kneifel. 2012. Monitoring transmission routes of Listeria spp. in smoked salmon production with repetitive element sequence-based PCR techniques. J. Food Prot. 75:504-511. http://dx.doi.org/10.4315/0362-028X. JFP-11-341. 